\title{
Saksan Liittotasavallan lapsilisäjärjestelmään ehdotetut muutokset
}

\author{
SIRKKA-LIISA KOLEHMAINEN
}

Syksyllä v. 1966 valmistui kahden vuoden työn tuloksena laaja Saksan Liittotasavallan sosiaaliturvaa koskeva ohjelma. Kyseisen ohjelman laatimisesta vastasivat seitsemän tunnettua professoria, joilta Liittotasavallan hallitus oli pyytänyt sosiaaliturvan uudelleen järjestämiseen liittyvää lausuntoa. Professorien suosituksessa paneudutaan kaiken muun ohella perusteellisesti myös lapsilisäkysymyksiin.

Voimassa olevan lapsilisäjärjestelmän perusteella maksetaan Liittotasavallassa lapsilisää porrastettuna toisesta lapsesta alkaen kumminkin siten, että toinen lapsi ei ole oikeutettu lapsilisään, jos vanhempien yhteenlasketut tulot ylittävät 7.800 DM.

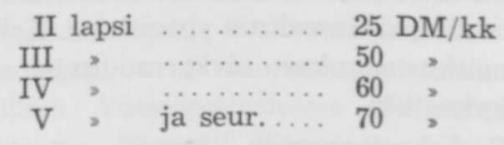

Lapsilisien lisäksi myönnetään palkannauttijoille myös verohuojennuksia, joiden määrä on riippuvainen lapsiluvusta ja palkan suuruudesta.

Taulukossa 1 on esitetty veron määrä III veroluokassa ja eri tuloluokissa lapsiluvun mukaan.

Taulukko 1. Veron määrä III veroluokassa tuloryhmittäin lapsiluvun mukaan nykyisessä järjestelmässä.

\begin{tabular}{lrrrrrrr}
\hline Tulo & \multicolumn{7}{c}{ Lasten lukumäärä } \\
DM/kk & 0 & 1 & 2 & 3 & 4 & 5 & 6 \\
\hline 430 & 0 & 0 & 0 & 0 & 0 & 0 & 0 \\
530 & 19 & 0 & 0 & 0 & 0 & 0 & 0 \\
670 & 46 & 27 & 0 & 0 & 0 & 0 & 0 \\
820 & 75 & 56 & 29 & 0 & 0 & 0 & 0 \\
970 & 103 & 84 & 57 & 29 & 0 & 0 & 0 \\
1120 & 132 & 113 & 86 & 57 & 29 & 0 & 0 \\
1270 & 160 & 141 & 114 & 86 & 57 & 29 & 0 \\
\hline
\end{tabular}

Tuloverotuksessa saadaan verotettavasta tulosta vähentää ensimmäisestä lapsesta 1.200 , toisesta 1.680 , kolmannesta ja kustakin seuraavasta $1.800 \mathrm{DM}$. Kun tuloveroasteikko on suhteellinen $16.000 \mathrm{DM}$ vuosituloon asti, saadaan verotuksessa huojennusta ensimmäisestä lapsesta $20 \mathrm{DM}$, toisesta 28 DM, kolmannesta ja kustakin seuraavasta 30 DM kuukaudessa. Nykyistä järjestelmää voidaan hyvällä syyllä kutsua kaksinaisjärjestelmäksi (Dual-System), koska perhekustannusten tasaaminen toteutetaan samanaikaisesti kahta eri tietä lapsilisien ja verohuojennusten kautta. Kokonaistasaus saadaan laskemalla mainitut tekijät yhteen:

\begin{tabular}{cccc}
\hline $\begin{array}{l}\text { Lasten jär- Lapsi- } \\
\text { jestysluku }\end{array}$ & $\begin{array}{l}\text { Veronhuo- } \\
\text { lisä }\end{array}$ & Yhteennus \\
\hline I & - & 20 & 20 \\
II & 25 & 28 & 53 \\
III & 50 & 30 & 80 \\
IV & 60 & 30 & 90 \\
V & 70 & 30 & 100 \\
\hline
\end{tabular}

Komitean suosituksessa puututaan nykyisen järjestelmän suurimpaan heikkouteen; nimittäin veronhuojennuksiin. Nämä ovat antaneet komitean jäsenille hyvän lähtökohdan tutkimukseen. Kuten edellä esitetystä taulukosta 1 havaitaan, lapsivähennykset eivät lisää palkannauttijan käytettävissä olevia tuloja sellaisessa tapauksessa, jolloin hän ei maksa tuloveroa. Esimerkiksi, jos henkilöllä on tuloa $530 \mathrm{DM} / \mathrm{kk}$ :ssa (kts. taulukko 1), hän joutuu maksamaan siitä veroa $19 \mathrm{DM}$ /kk:ssa. Jos hänellä on yksi lapsi, tästä tulosta ei peritä veroa. Tällöin henkilö ei voi saada veronhuojennusta, koska hän ei maksa verojakaan.

Komitea ehdottaa, että lapsilisän muodostaisi nykyisin maksettu lapsilisä lisät- 
tynä nykyisellä veronhuojennuksella. Lisäksi ensimmäinenkin lapsi olisi oikeutettu tähän yhdistettyyn tukeen. Lapsilisät olisivat siten seuraavat:

\begin{tabular}{|c|c|c|c|}
\hline & apsi & 20 & \\
\hline II & , & 50 & \\
\hline III & ? & 80 & \\
\hline IV & , & 90 & \\
\hline V & , & 100 & \\
\hline
\end{tabular}

Kyseiseen lapsilisään olisi oikeutettu jokainen lapsi siitä riippumatta, onko vanhemmilla verotettavaa tuloa vai ei. Lapsilisän maksamisen tulisi tapahtua palkanmaksun yhteydessä siten, että työnantaja alentaa veronpidätystä lapsilisän verran ennalta laadittujen verotaulukkojen ja uusitun verokirjan mukaan. Esim. henkilö, jolla on 1212 DM tuloa kuukaudessa ja kaksi lasta, maksaisi veroa taulukko 2:n mukaan 79 DM kuukaudessa ja saisi lapsilisää $70 \mathrm{DM}$ kuukaudessa. Uuden järjestelmän mukaan hänen tarvitseekin maksaa veroa vain 9 DM kuukaudessa. Henkilöille, joilla palkan pienuuden tai lapsiluvun perusteella ei ole verotettavaa tuloa, maksettaisiin lapsilisää suoraan valtion varoista. Samoin voidaan joutua osittain korvaamaan lapsilisä silloin kun verronalennukset ovat lapsilisää pienemmät.

Lapsiluvusta ja tuloryhmistä johtuvat veronhuojennukset jäisivät voimaan, kumminkin komitean ehdotuksen mukaan nykyistä tehokkaammin porrastettuina.

Kun verrataan ehdotettua järjestelmää voimassa olevaan, niin ehdotetut muutokset vaikuttavat seuraavasti.

1. Ensimmäinenkin lapsi tulisi nyt saamaan lapsilisää, t.s. kaikki ensimmäiset lapset saisivat lapsilisinä saman edun, jonka veroa maksavat nykyisin saavat veronhuojennuksina.

2. Tuloraja poistuisi toisen lapsen kohdalta.

3. Erikoisen voimakas vaikutus on sillä, että kaikkiin ehdotettuihin lapsilisiin sisältyisi myös nykyisin myönnettävä veronhuojennus. Tällöin myöskin ne
Taulukko 2. Veron määrä vero-luokassa III tuloryhmittäin lapsiluvun mukaan ehdotetussa järjestelmässä.

\begin{tabular}{lrrrrrr}
\hline Tulo & \multicolumn{7}{c}{ Lasten lukumäärä } & & \\
DM/kk & 0 & 1 & 2 & 3 & 4 & 5 \\
\hline 430 & 0 & 0 & 0 & 0 & 0 & 0 \\
530 & 19 & 0 & 0 & 0 & 0 & 0 \\
799 & 70 & 51 & 0 & 0 & 0 & 0 \\
1212 & 149 & 130 & 79 & 0 & 0 & 0 \\
1679 & 239 & 219 & 167 & 88 & 0 & 0 \\
2197 & 359 & 334 & 276 & 192 & 100 & 0 \\
\hline
\end{tabular}

henkilöt, jotka nykyisin eivät pääse osallisiksi näistä veronhuojennuksista tulojensa pienuuden tai lapsiluvun perusteella tulisivat saamaan kyseisen veronhuojennuksen.

4. Verovapaa toimeentulominimi kohoaisi tuntuvasti nykyisestä varsinkin monilapsisten perheiden kohdalla, t.s. tuloverosta vapautuisi moni sellainen perhe, joka nyt on veron piirissä.

5. Lapsilisäjärjestelmän hallintokustannuksiin saataisiin komitean laskelmien mukaan säästöä, kun lapsilisät maksettaisiin palkanmaksun yhteydessä. Kokonaiskustannukset eivät muuttuisi nykyisestään.

6. Perhekustannusten tasaus toteutuisi uudessa järjestelmässä nykyistä paremmin, koska nykyinen veronhuojennus suosii enemmän suurituloisia kuin pienituloisia. Kun veroasteikko on progressiivinen ja kun lapsivähennykset tehdään verotettavasta tulosta, lapsivähennys merkitsee nyt sitä suurempaa markkamääräistä etua kuta suuhemmat tulot ovat kyseessä. Suurituloiset eivät hyötyisi uuden järjestelmän mukaan vaan kaikki saisivat samansuuruisen edun tulojen suuruudesta riippumatta.

(Lähde: Soziale Sicherung, Sozialenquête, in der Bundesrepublik Deutschland. Bericht der Sozialenquête-Kommission, W. Kohlhammer GmbH., Bonn 1966.) 